\title{
Ushering towards Green Management (A Case Study of Select Educational Institutes in Rajasthan)
}

\author{
Dr. Richa Nangia ${ }^{1}$ \\ ${ }^{\text {I}}$ (Department of Management \& Commerce/ K R Mangalam University, Gurgaon, India)
}

\begin{abstract}
Now days, there has been a major change in environmental management activities worldwide in all fields of activity including the education industry. The institutes and universities are adopting new concept of "Sustainability and ecofriendly activities" in their daily operations. While earlier it was a passive concept of "Environmental Protection", now it has become a rather proactive approach.

Green management explains about management of all the organizational activities which have no negative impact on the global or local environment, community, society, and economy. It is all about putting the four R's - Reduce, Reuse, Recycle and Recover the resource into action. Such activities in educational institutes are not only ushering students to show their creativity and innovation in devising ways and means of environmental conservation, but are also finding great popularity among students and the management a like.

Rajasthan is one state in India which has a shortage of many natural resources. . To survive and thrive, especially in a state like Rajasthan developing mechanisms, which enable successfully answer the environmental demand of regulators, stakeholders including students and society is the need of the hour. Good environmental performance is here more than a matter of compliance and cost. Natural Conservation and preservation is a part of the living culture here. Many institutes in Rajasthan are participating in environmentally friendly or green activities to ensure that all processes and activities adequately address current environmental concerns while maintaining cost effectiveness. This research was conducted with the aim of mapping the level of awareness and action orientation of select educational institutes of the state of Rajasthan. The findings bring to the fore the efforts that have been put by these institutes towards "Green Management". For the purpose of this research a sample of 50 members of management from colleges across Rajasthan was taken. The respondents marked their responses on a semi structure questionnaire relating to Green Management.
\end{abstract}

Keywords: Eco-production, Environmental Protection, Green Management, Natural Conservation, Regulators and Stakeholders.

\section{Introduction}

Green management initiative is an important factor in forward thinking business around the world. Employees must be inspired, empowered and environmentally aware of greening in order to carry out green management initiatives. More so, in the education institutions- since they are the sculptures' of the future generations. There is a growing need for the integration of environment into management system irrespective of the industry - Green Management. Green Management is defined as the process whereby organizations manage the environmental management strategies in which companies need to balance between industrial growth and safeguarding the natural environment so that future generation may flourish. Green management refers to the management of corporate interaction with and its impact on the environment and it needs to include conceptual tools such as pollution prevention, product stewardship and corporate social responsibility. Educational institutes can play a vital role in the issue relating to environment management since they are the part of the society and cannot be isolated from the environment. Moreover they have the capability and responsibility to inculcate environmental sensitivities in the youth. Green Management can be effectively implemented in them if they have the support of the top management with the right sensitivity and motivation. Green management should be practiced as a whole and must be aligned with the environment management strategies. It therefore becomes their responsibility that they put in more efforts into the research on innovative technology and environmental sustainability to minimize the impact of environmental destruction and pollution on environment.

\section{Objectives Of The Study}

This research is conducted with the aim of mapping the level of awareness and action orientation about Green Management of select educational institutes of the state of Rajasthan. The study shall have following objectives: 
1. To understand the green management practices those are being carried out by the educational institutes of Rajasthan.

2. To study the impact of green practices on environment as well as on students and employees.

3. To discover various Challenges while implementing green practices in educational institutes.

\section{Research Methodology}

Research methodology is the organized process of collecting and analyzing information in order to increase our understanding of the phenomenon about which we are concerned or interested. The main aim of research is to find out the truth which is hidden and which has not been discovered as yet.

During the research the critical stage is the stage of data collection. It needs maximum attention of researcher, as data is the base for whole of research undertaken. In this research both primary and secondary data has been collected to present a comprehensive analysis on Green Management of select educational institutes of the state of Rajasthan.

* Primary Data: The study is mostly founded upon gathering of comprehensive data from primary sources like - in-person surveys, interviews etc. comes under primary data.

* Secondary Data: The research was carried out depending on secondary sources which require no direct contact to gather information and is effectively based upon postal mail, electronic mail, telephone, web-based surveys, newspapers, business journals and periodicals, etc.

For the purpose of this study the higher education sector was chosen and further divided into three homogenous groups:

Academic Colleges: This included graduate as well as post graduate level colleges which run courses like B.A., B.Com. B.Sc., M.A., M.Sc. etc.

Technical Colleges: This includes graduate as well as post graduate level colleges which run courses like B.tech, M.Tech, MCA etc.

Management Colleges: This includes graduate as well as post graduate level colleges which run courses like B.B.A. \& M.B.A., PGDBM.

The questionnaires were sent through the mail to the colleges in selected cities i.e. Udaipur, Jaipur, Jodhpur and Kota in Rajasthan.

This research comprises of the following tools for data collection:

- Questionnaire

- Interviews \& Interaction with people in the Management

- Extensive literature survey

\section{Green Management In Education Sector}

The mission of educational institutions in General is to increase the intellectual wealth of the Commonwealth, to prepare students at all levels for personal and professional success in their lives, and to contribute to the economic, social, and cultural development of country and Rajasthan state in particular.

While being a part of the "Educational System" denotes a common cord, each college/university has distinctiveness in programs, services, students served, and its relationship with its societies and regions. This philosophy tends to migrate to the "green concepts" as well. Generally all colleges/universities have a commitment to environmental stewardship and sustainable opportunities, their emphasis and approach to a particular concept or technology varies from one university to another.

The System continually looks for ways to improve their operations to more closely align themselves with the latest sustainable concepts and technologies. Each university is committed to evaluating green opportunities and implementing them where the application makes sense. Every campus can boast of numerous green initiatives that they have implemented over the years;

Green Management is a term that encompasses a wide-array of topics. For the purposes of this research, we have divided this section into the following areas:

- General - covers management initiatives, directives and interesting items that may not fit into other categories

- Energy Management/Reduction - initiatives the colleges are taking, some which are very innovative, to effectively manage energy consumption and reduce energy costs

- Green Curriculum - specific to colleges, the System takes this opportunity to showcase academic course offerings specific to a sustainable future and the environment.

- Hazardous Waste Management - what the universities are doing above and beyond regulatory requirements to manage waste and minimize waste generation. 


\section{Sustainable Development In Education Sector}

Sustainable development (SD) is a pattern of growth in which resource use aims to meet human needs while preserving the environment so that these needs can be met not only in the present, but also for generations. The term sustainable development was used by the Brundtland Commission which coined what has become the most often-quoted definition of sustainable development as development that "meets the needs of the present without compromising the ability of future generations to meet their own needs.

Sustainable development ties together concern for the carrying capacity of natural systems with the social challenges facing humanity. As early as the 1970s "sustainability" was employed to describe an economy in equilibrium with basic ecological support systems. Environmentalists have pointed to the limits to Growth, and presented the alternative of a stable state economy in order to address environmental concerns.

The field of sustainable development can be conceptually broken into three constituent parts: environmental sustainability, economic sustainability and sociopolitical sustainability.

The broad goals of sustainable development in education sector are;

- To provide an opportunity for promoting the vision of and transition to sustainable development through education, public awareness and training; and

- To integrate and enhance the role of education and learning in sustainable development.

The three spheres of activities identified for sustainable development are;

- environmental protection;

- social development; and

- Economic development.

The four identified major thrusts for sustainable development, adopted Indian education sector include;

- improving access to quality higher education;

- reorienting existing education programmes;

- developing public understanding and awareness; and

- Providing training regarding green management.

\section{Sustainable Development, the Environment and Education}

According to UNESCO's recent documents, Sustainable Development is the ultimate goal of the manenvironment relationship. The inclusion of Environmental Education (EE) in the broader scope of education for the development of responsible societies is being considered. Environmental Education is about education for, education through and education about the environment.

Sustainable Development paves the way for a sustainable future. Sustainable future is about 'thinking about forever'. Education for a Sustainable Future (ESF) means committing ourselves to the common good by broadening our perspectives, clarifying what we value, connecting with our neighbors, and providing hope for future generations. Building the capacity to think in terms of 'forever' is a key task of this form of education.

ESF involves a comprehensive approach to educational reform. It extends beyond individual school subjects and requires the attention of teachers, educational administrators, planners and curriculum agencies. Orienting the objectives, concepts and learning experiences of ESF into syllabi and teaching practices is an important part of this reform.

A basic premise of education for sustainability is that just as there is a wholeness and interdependence to life in all its forms, so must there be a unity and wholeness in the efforts to understand it and ensure its continuation. This calls for both interdisciplinary inquiry and action.

Table No.1

\section{Figures And Tables}

\begin{tabular}{|c|c|}
\hline Category of Colleges & Percentage of Colleges following Green Initiatives \\
\hline Academic & 60 \\
\hline Technical & 80 \\
\hline Management & 70 \\
\hline
\end{tabular}


Figure No. 1

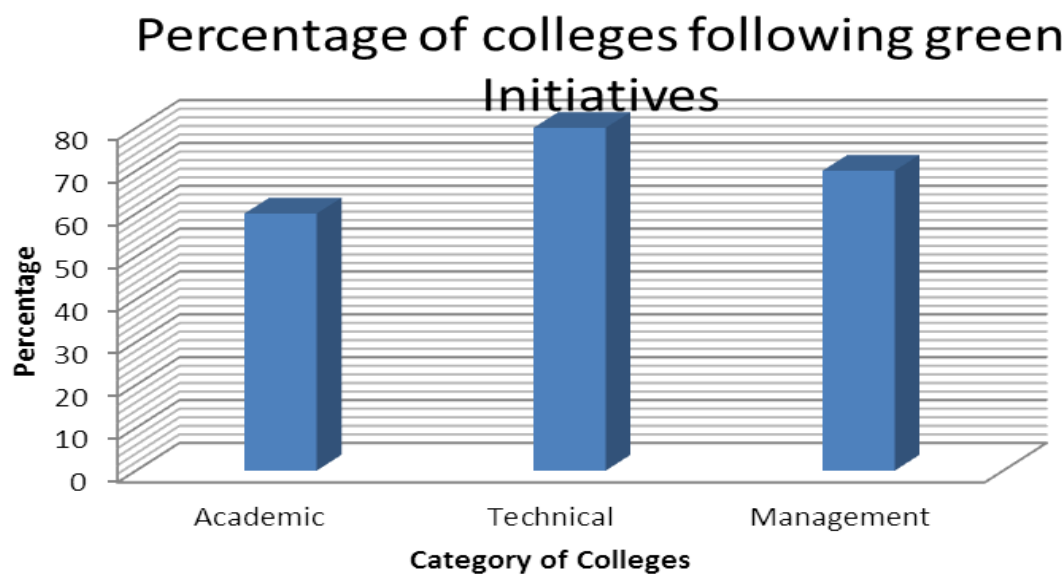

Table \& Figure No. 1 shows that Percentage of colleges following green Initiatives. 60\% academic colleges, $80 \%$ Technical colleges and 70\% management colleges which are covers management initiatives like tree plantation on special days or occasions, water harvesting, paper \& pen recycling, tying of parindas (water containers for birds) on trees and other places and similar other activities, computerization and use of MIS. Many colleges are using the electronic media like email and SMS to communicate officially. They conduct special drives from time to time to fulfill their Corporate Social responsibility and make the students and teachers aware and sensitive to environmental issues.

Table No.2

\begin{tabular}{|c|c|}
\hline Category of Colleges & Percentage of Colleges following Energy Management \\
\hline Academic & 60 \\
\hline Technical & 70 \\
\hline Management & 50 \\
\hline
\end{tabular}

Figure No. 2

\section{Percentage of colleges following energy management}

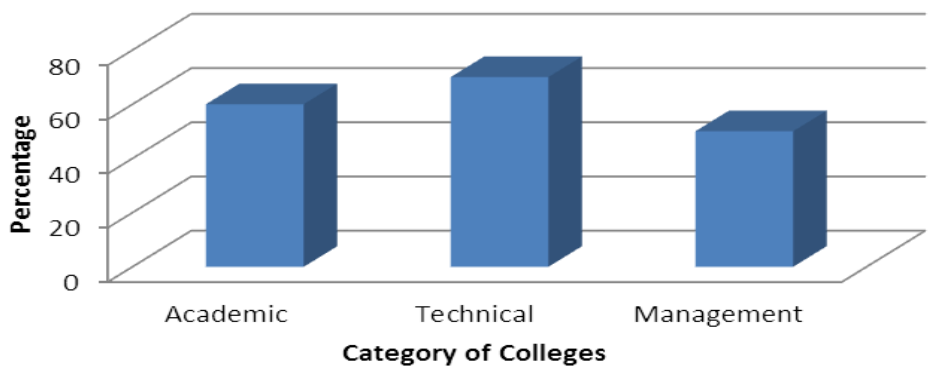

Table \& Figure No. 2 shows that Percentage of colleges following energy management. $60 \%$ academic colleges, $70 \%$ Technical colleges and 50\% management colleges are working towards energy management especially electricity management and petrol management through car pooling and use of college buses for transport.

Table No.3

\begin{tabular}{|c|c|}
\hline Category of Colleges & Percentage of Colleges following Green Curriculum \\
\hline Academic & 0 \\
\hline Technical & 50 \\
\hline Management & 30 \\
\hline
\end{tabular}


Figure No. 3

\section{Percentage of colleges following green curriculum}

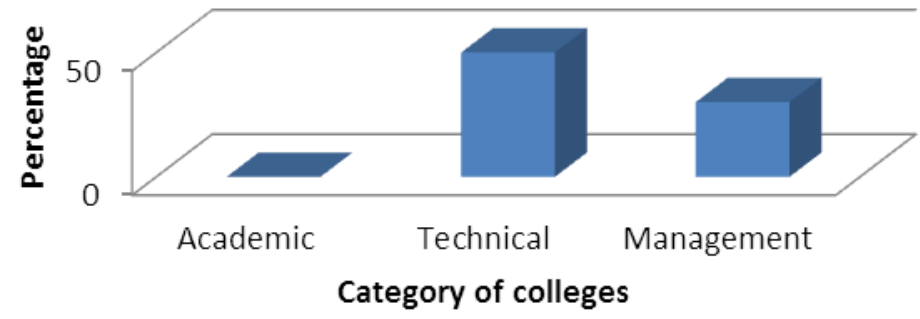

Table \& Figure No. 3 shows that Percentage of colleges following green curriculum. 0\% academic colleges, $50 \%$ Technical colleges and 30\% management colleges imbibe topics related to environmental awareness, sustainable development like green marketing, green computing, environmental and disaster management as a part of their curriculum.

Table No.4

\begin{tabular}{|c|c|}
\hline Category of Colleges & Percentage of colleges following Waste Management \\
\hline Academic & 30 \\
\hline Technical & 30 \\
\hline Management & 20 \\
\hline
\end{tabular}

Figure No. 4

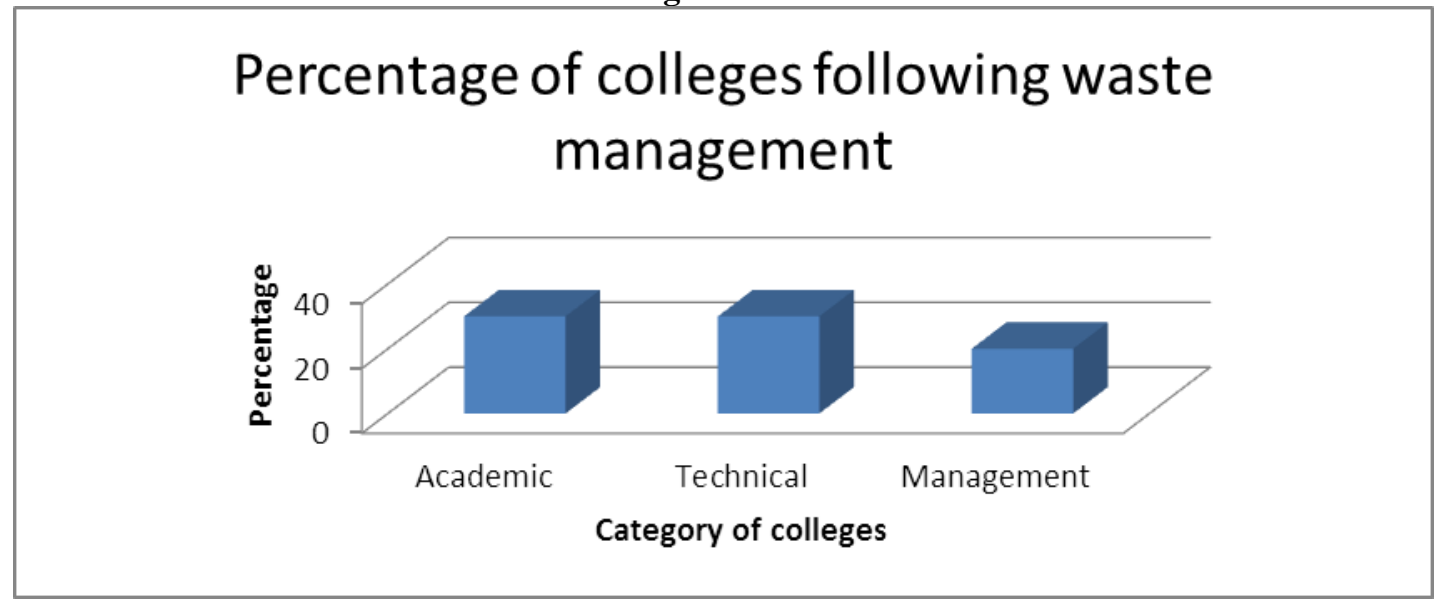

Table \& Figure No. 4 shows that Percentage of colleges following waste management. 30\% academic colleges, $30 \%$ Technical colleges and $20 \%$ management colleges are following waste management like water recycling, proper disposal of toxic waste from laboratories etc., manure making through waste and leaves.

\section{Key Challenges To Implementing A Green Programme Include:}

- Cost: Generally it is believed that the effort towards going green requires a lot of money. The initiation of such projects is both costly and cumbersome. The short term cost of establishing green initiatives certainly increases the bill with no apparent benefit to the organization as such. None the less, organizations who have followed this path for a longer period of time confess that the benefits are many fold.

- $\quad$ Lack of Support: The support of top management is the fundamental requirement for effectiveness of the green practices. Many management people are unsupportive of such initiatives as they feel that such activities are futile and wasteful.

- Internal education and regulation: For the successful implementation of sustainability programs, cooperation of the faculty and students alike is imperative. This requires efforts and training of the faculty, non teaching staff as well as students so that their mindset towards the green initiatives remains positive and they volunteer in such exercises. 
- $\quad$ Time to implementation: Green initiatives need articulate planning and execution, since the concept is not very popular, implementing it in a proper manner requires time and patience. The initiatives have large gestation period before they start showing desirable results.

\section{Conclusion}

The role of education in facilitating social and economic progress is well recognized. It is empirically proved that education which is one of the components of human capital impacts economic growth positively. Improvement in education can improve life skills, learning skills and livelihood skills which in turn can raise the overall quality of life. In addition, the strengthening of education sector can play an instrumental role in achieving rapid and inclusive growth. In this knowledge intensive world driven by information technology, higher education is a must and its importance cannot be ignored. The educational institutes are doing a lot to create awareness regarding issues of green management and implementing them on local levels, However, they can contribute a lot more for the environmental sustainability, by not only doing something on their level but also by inculcating the sense of sustainability in the students which will go a long way in keeping our mother Earth livable for a long time to come.

\section{References}

[1]. Seema Joshi, Sustainable Development of the Higher Education Sector in India for Catalyzing Services-Driven Growth, Working Paper No. 2012/01, Maastricht School of Management.

[2]. http://www.aiuweb.org/Notifications/Foreign\%20Education\%20Providers\%20Bill.pdf

[3]. http://www.fibre2fashion.com/news/textiles-fashion-hr- news/ newsdetails.aspx

[4]. Agarwal, Pawan, Higher Education in India: The Need for Change, ICRIER Working Paper, June 2006.

[5]. http://en.wikipedia.org/wiki/Sustainable_development

[6]. Bill Roth, The Secret Green Sauce, Published by NCCT,USA 2009.

[7]. Daniel C. Esty and Andrew S. Winston, Green to Gold: How Smart Companies Use Environmental Strategy to Innovate, Create Value, and Build Competitive Advantage, published by John Wiley \& Sons, New Jersey 2009.

[8]. Psacharopoulos,George "The Value of Investments in Education: Theory, Evidence and Policy" Journal of Education Finance, (2006), 32(2):113-36.

[9]. Dreze, Jean and Amartya Sen “India: Economic Development and Social Opportunity” Delhi Oxford University Press 1996. 